\title{
NAKAZ DOKONYWANIA WYKŁADNI PROUNIJNEJ JAKO DYREKTYWA WYKLADNI SYSTEMOWEJ
}

\section{WPROWADZENIE}

Przystapienie do Unii Europejskiej włączyło Polskę do unijnego porządku prawnego, co spowodowało zarówno konieczność bezpośredniego stosowania norm wynikających z aktów prawnych ustanowionych przez odpowiednie organy Unii Europejskiej, jak i nakaz dokonywania przez organy stosujące prawo, w szczególności sądy poszczególnych krajów członkowskich, tzw. prounijnej wykładni prawa krajowego ${ }^{1}$. Ten ostatni obowiązek przyniósł polskiej teorii prawa nowe wyzwania i problemy. Należy zauważyć przy tym, że mimo bogactwa opracowań dotyczących problematyki wykładni prounijnej, kwestia statusu metodologicznego nakazu dokonywania wykładni przepisów prawa krajowego w zgodzie z prawem unijnym nie jest częstym przedmiotem rozważań. W nauce prawa przeważa pogląd, że nakaz ten jest dyrektywą wykładni systemowej2. Celem artykułu jest zweryfikowanie tego stanowiska oraz zarysowanie własnego.

\footnotetext{
${ }^{1}$ Należy zaznaczyć, że przed wejściem w życie traktatu z Lizbony zmieniającego Traktat o Unii Europejskiej i Traktat ustanawiający Wspólnotę Europejską z 13 grudnia 2007 r., Dz. Urz. UE C 2007, nr 306, poz. 1) posługiwano się dwoma terminami: „wykładnia prowspólnotowa” i „wykładnia prounijna”; pierwszy - miał podstawowe znaczenie w praktyce - na określenie wykładni dokonywanej w zgodzie z prawem wspólnotowym ujętym w I filarze, natomiast drugi termin - stosunkowo rzadko używany - przeznaczony był dla wykładni prawa krajowego w zgodzie z prawem unijnym ujętym w II i III filarze. Po wejściu w życie traktatu z Lizbony i zniesieniu podziału na filary, podstawowe znaczenie ma wykładnia prounijna, a sformułowania „wykładnia prowspólnotowa” należałoby używać wyłącznie w stosunku do wykładni prawa krajowego w zgodzie z prawem Europejskiej Wspólnoty Energii Atomowej (EURATOM) - por. M. Koszowski, Wyktadnia prawa krajowego $w$ zgodzie z prawem Unii Europejskiej po uwzględnieniu zmian spowodowanych wejściem w życie Traktatu z Lizbony, „Studia Prawa Prywatnego” 2012, z. 2(25), s. 60-61; K. Kowalik-Bańczyk, Prowspólnotowa wyktadnia prawa polskiego, „Europejski Przegląd Sądowy” 2005, nr 3, s. 16-18. Por. M. Koszowski, Wyktadnia prowspólnotowa w ujęciu teoretycznoprawnym, „Przegląd Legislacyjny” 2009, nr 3, s. 70-72.

2 T. Chauvin, T. Stawecki, P. Winczorek, Wstep do prawoznawstwa, Warszawa 2009, s. 241; L. Morawski, Zasady wyktadni prawa, Toruń 2014, s. 143-147.
} 


\section{PODSTAWOWE ZALOŻENIA WYKLADNI PROUNIJNEJ ORAZ WYKŁADNI SYSTEMOWEJ}

W celu usystematyzowania dalszego wywodu niezbędne jest przypomnienie podstawowych założeń dotyczących zarówno wykładni prounijnej, jak i systemowej. Obowiązek wykładni prounijnej (prowspólnotowej) nie został wprost wyrażony w prawie unijnym czy wcześniej wspólnotowym, Trybunał Sprawiedliwości wywiódł go z trzech fundamentalnych zasad sformułowanych w swoim orzecznictwie: zasady pierwszeństwa prawa unijnego wobec prawa krajowego, zasady efektywności prawa wspólnotowego oraz lojalności państw członkowskich wobec wspólnoty ${ }^{3}$. W doktrynie jako podstawę prawną obowiazku dokonywania wykładni prowspólnotowej podawano art. 10 Traktatu ustanawiającego Wspólnotę Europejską (wcześniej art. 5), kreującego zasadę lojalności (solidarności) oraz art. 249 akapit 3 Traktatu ustanawiającego Wspólnotę Europejską oraz tzw. klauzule wzajemnego powiązania w przypadku dyrektyw ${ }^{4}$. Sa to przepisy końcowe dyrektyw zawierające zobowiązanie państwa do pełnej implementacji danej dyrektywy ${ }^{5}$. Zasady te obecnie zostały zawarte w art. 4 ust. 3 Traktatu o Unii Europejskiej. Jako podstawę prawna obowiązu dokonywania wykładni prowspólnotowej w polskim prawie wskazywano w okresie przedakcesyjnym art. 68 Układu Europejskiego ${ }^{6}$ oraz art. 91 ust. $1 \mathrm{Konstytucji}^{7}$, a po przystapieniu do Unii Europejskiej - art. 91 ust. 3 Konstytucji ${ }^{8}$.

Zasadnicza idea wykładni prounijnej została ujęta w trzech orzeczeniach Trybunału Sprawiedliwości: pierwszym z 10 kwietnia 1984 r. w sprawie von Colson, drugim z 13 listopada 1990 r., w sprawie Marleasing i trzecim

${ }^{3}$ Por. C. Mik, Wyktadnia zgodna prawa krajowego z prawem Unii Europejskiej, w: S. Wronkowska (red.), Polska kultura prawna a proces integracji europejskiej, Kraków 2005, s. 124; M. Koszowski, Wyktadnia prawa krajowego w zgodzie z prawem Unii Europejskiej po uwzględnieniu zmian spowodowanych wejściem w życie Traktatu z Lizbony, „Studia Prawa Prywatnego” 2012, z. 2(25), s. 60-62; A. Kalisz, Wyktadnia i stosowanie prawa wspólnotowego, Warszawa 2007, s. 199, 201-202; W. Postulski, Sady państw członkowskich jako sqdy wspólnotowe, w: A. Wróbel (red.), Stosowanie prawa Unii Europejskiej przez sqdy, Kraków 2005, s. 436; K. Płeszka, Wyktadnia rozszerzajaca, Warszawa 2010, s. 240.

${ }^{4}$ Por. M. Koszowski, Wyktadnia prowspólnotowa..., s. 70-71; C. Mik, op. cit., s. 124-125; K. Kowalik-Bańczyk, op. cit., s. 10; S. Biernat, Wyktadnia prawa krajowego zgodnie z prawem Wspólnot Europejskich, w: C. Mik (red.), Implementacja prawa integracji europejskiej $w$ krajowych porzadkach prawnych, Torun 1998, s. 130.

${ }^{5}$ Por. M. Koszowski, Wyktadnia prowspólnotowa..., s. 71; J. Dudzik, Wyktadnia przepisów krajowych jako metoda implementacji-pośrednia skuteczność dyrektyw, w: L. Leszczyński (red.), Wyktadnia prawa-odrębności w wybranych gatęziach prawa, Lublin 2006, s. 170-171.

${ }^{6}$ Układ Europejski ustanawiający stowarzyszenie między Rzeczapospolitą Polska, z jednej strony, a Wspólnotami Europejskimi i ich Państwami Członkowskimi, z drugiej strony, sporzadzony w Brukseli 16 grudnia 1991 r., Dz. U. 1994, Nr 11, poz. 38 ze zm.; por. S. Sołtysiński, Dostosowanie prawa polskiego do wymagań Układu Europejskiego, „Państwo i Prawo” 1996, z. 4, s. 31-43.

${ }^{7}$ Wyrok TK z 28 stycznia 2003 r., K 2/02, OTK-A 2003, nr 1, poz. 4, Dz. U. 2003, Nr 24, poz. 202.

${ }^{8}$ L. Morawski, Zasady..., s. 296-297. 
z 4 lipca 2006 r. w sprawie Adeneler ${ }^{9}$. W sprawie von Colson Trybunał stwierdził, że „do sądu krajowego należy, na ile to jest możliwe w ramach swobodnej oceny, przyznanej mu przez prawo krajowe, dokonanie takiej wykładni i takie stosowanie przepisów wydanych w celu wykonania dyrektywy, które będa zgodne z wymogami prawa wspólnotowego" ${ }^{10}$. Obowiąek wykładni prounijnej sprowadzał się do wyboru rozwiązania w granicach uznania dopuszczalnego przez prawo krajowe. W orzeczeniu w sprawie Marleasing Trybunał Sprawiedliwości rozszerzył zakres obowiązku wykładni prounijnej, podkreślając, że sięga ona „tak daleko, jak to jest możliwe”, aby osiagnąć cel dyrektyw ${ }^{11}$. Zadaniem sądu krajowego jest przeprowadzanie wykładni prawa krajowego tak, aby w największym możliwym stopniu osiagnać cel dyrektyw ${ }^{12}$. Pogląd ten został doprecyzowany w wyroku z 4 lipca 2006 r. w sprawie Adeneler. Trybunał stwierdził, że zasada zgodnej wykładni wymaga, by sądy krajowe czyniły wszystko, co leży w zakresie ich kompetencji, uwzględniajacc wszystkie przepisy prawa krajowego i stosując uznane w porządku krajowym metody wykładni, by zapewnić pełną skuteczność rozpatrywanej dyrektywy i dokonać rozstrzygnięcia zgodnego z realizowanymi przez nią celami ${ }^{13}$. Jednocześnie Trybunał zaznaczył, że „spoczywający na sądzie krajowym obowiązek odniesienia się do treści dyrektywy przy dokonywaniu wykładni i stosowaniu odpowiednich przepisów prawa krajowego jest ograniczony przez ogólne zasady prawa, w szczególności zasadę pewności prawa i braku retroaktywności prawa, i nie może służyć jako podstawa dla dokonywania wykładni prawa krajowego contra legem" ${ }^{14}$. Do tak sformułowanego obowiązku wykładni zgodnej Trybunał Sprawiedliwości odwoływał się konsekwentnie w kolejnych orzeczeniach ${ }^{15}$. Trzeba podkreślić, że z punktu widzenia Trybunału Sprawiedliwości istotny jest jedynie rezultat wykładni prounijnej prawa krajowego, a nie jej przebieg. Tę kwestię pozostawiono koncepcjom wykładni poszczególnych krajów członkowskich.

${ }^{9}$ Wyrok TS z 10 kwietnia 1984r. w sprawie 14/83 - Sabine von Colson i Elizabeth Kamann przeciwko Land Nordrhein-Westfalen, ECR 1984, s. 1891, teza 26 i 28; wyrok TS z 13 listopada 1990 r., w sprawie C-106/89 - Marleasing SA v. La Comercial International de Alimentacion SA, ECR 1990, s. I-4135, polskie tłumaczenie opublik. w: Lex, nr 124953; wyrok TS z 4 lipca 2006 r. w sprawie C-212/04 - Konstantinos Adeneleri inni v. Ellinikos Organismos Galaktos (ELOG), ECR 2006/7A/I-06057, t. 111.

${ }^{10}$ Wyrok TS z 10 kwietnia 1984 r. w sprawie 14/83 - Sabine von Colson i Elizabeth Kamann przeciwko Land Nordrhein-Westfalen, ECR 1984, s. 1891, t. 26 i 28.

${ }_{11}$ Por. T. Koncewicz, Sędziowski obowiazek interpretacji prawa krajowego w zgodzie z prawem wspólnotowym, „Przegląd Sądowy” 2000, nr 6, s. 36.

${ }_{12}$ Por. K. Pleszka, op. cit., s. 240; A. Kalisz, op. cit., s. 241.

${ }^{13}$ Wyrok TS z 4 lipca 2006 r. w sprawie C-212/04 - Konstantinos Adeneleri inni v. Ellinikos Organismos Galaktos (ELOG), ECR 2006/7A/I-06057, t. 111.

${ }^{14}$ Ibidem, t. 110.

${ }_{15}$ Por. wyrok TS z 24 stycznia 2012 r. w sprawie C-282/10 - Maribel Dominguez v. Centre informatique du Centre Ouest Atlantique, Préfet de la région Centre, www.eur-lex.europa.eu; wyrok TS z 15 kwietnia 2008 r. w sprawie C-268/06 - Impact v. Minister for Agriculture and Food i inni, ECR 2008/4B/I-02483, p. 100; wyrok TS z 23 kwietnia 2009 r. w sprawie C-378/07 - Kiriaki Angelidaki i inni v. Organismos Nomarchiakis Autodioikisis Rethymnis i Charikleia Giannoudi, Georgios Karabousanos i Sofoklis Michopoulos v. Dimos Geropotamou, pkt 199, www.eur-lex.europa.eu. 
W nauce prawa w rozmaity sposób definiuje się pojęcie dyrektyw interpretacyjnych. Jerzy Wróblewski uważa je za dyrektywy, które wyznaczają znaczenie danego przepisu, i dzieli na dyrektywy interpretacyjne pierwszego stopnia, które wskazuja jak interpretator powinien ustalać znaczenie przepisu ze względu na podstawowe konteksty, w jakich on występuje, oraz dyrektywy interpretacyjne drugiego stopnia, które wyznaczaja sposób posługiwania się dyrektywami pierwszego stopnia ${ }^{16}$. Lech Morawski definiuje regułę wykładni jako argument, który przemawia za przyjęciem albo odrzuceniem określonego znaczenia danego wyrażenia ${ }^{17}$. W ujęciu derywacyjnym Zygmunt Ziembiński określa je ogólnie jako reguły przekładu przepisów prawnych na normy ${ }^{18}$, a Maciej Zieliński charakteryzuje jako dyrektywy celowościowe wskazujace sposób postępowania, który jest skuteczny dla osiagnięcia celu interpretacyjnego, a zatem w ostateczności dla ustalania sensu odtworzonej z przepisów normy prawnej ${ }^{19}$.

Wykładnia systemowa jest zespołem czynności zmierzających do odtworzenia norm prawnych z przepisów prawnych, uwzględniając system prawny, do którego należą. Dyrektywy wykładni systemowej opierają się na trzech zasadniczych założeniach dotyczących systemu prawa - jego spójności, uporządkowaniu i zupełności ${ }^{20}$. Dany system prawny jest spójny wewnętrznie, jeżeli jest wolny od niezgodności, zarówno formalnych, jak prakseologicznych ${ }^{21}$. Uporządkowanie polega na tym, że przepisy pogrupowane sa treściowo (systematyzacja pozioma), jak i hierarchicznie (systematyzacja pionowa) ${ }^{22}$. Natomiast zupełność systemu prawa przede wszystkim wiąże się z tym, że jest on pozbawiony luk ${ }^{23}$.

Konsekwencją założeń o uporządkowaniu systemu prawnego jest dyrektywa wykładni systemowej nakazująca respektowanie hierarchii aktów normatywnych. Hierarchia ta $\mathrm{w}$ polskim systemie prawa została wprost określona w art. 87 ust. 1 i 2 Konstytucji Rzeczypospolitej Polskiej. W hierarchii powszechnie obowiązujących źródeł prawa Rzeczypospolitej Polskiej najwyżej

${ }^{16}$ J. Wróblewski, op. cit., s. 117-120.

${ }^{17}$ L. Morawski, Zasady..., s. 61-68. Autor podkreśla, że dyrektywy wykładni są dyrektywami uzasadniania, a nie dyrektywami heurystycznymi, a także zwraca uwage na niekonkluzywny charakter większości reguł wykładni, odróżniając je od dyrektyw inferencyjnych stosowanych w logice formalnej. Podobnie charakteryzuja dyrektywy wykładni T. Chauvin, T. Stawecki, P. Winczorek, op. cit., s. 239. „Zauważyć należy, że uzasadnienie decyzji interpretacyjnej polega na przytaczaniu odpowiednich argumentów na rzecz takiego lub innego znaczenia normy. Argumenty te nazywamy dyrektywami wykładni lub dyrektywami interpretacyjnymi”. W innym miejscu jednak autorzy podaja, że reguły wykładni to reguły „przekładania przepisów zawartych w aktach normatywnych na kompletne normy postępowania" - ibidem, s. 99. Szerzej na temat charakteru metodologicznego dyrektyw interpretacyjnych - L. Morawski, Spory o wyktadnie, wykład wygłoszony na Wydziale Prawa i Administracji Uniwersytetu Warszawskiego w listopadzie 2011 r., s. 1-8, www.wpia.uw.edu.pl; J. Leszczyński, O charakterze dyrektyw wykładni prawa, „Państwo i Prawo” 2007, z. 3, s. 28-44.

${ }^{18}$ S. Wronkowska, Z. Ziembiński, Zarys teorii prawa, Poznań 1997, s. 155.

19 M. Zieliński, Wyktadnia prawa. Zasady, reguty, wskazówki, Warszawa 2012, s. 285.

${ }^{20}$ L. Morawski, Zasady..., s. 125-127.

${ }^{21}$ S. Wronkowska, Z. Ziembiński, op. cit., s. 181-182.

${ }^{22}$ L. Morawski, Zasady..., s. 125-127.

${ }^{23}$ S. Wronkowska, Z. Ziembiński, op. cit., s. 183-185. 
znajduje się Konstytucja, następnie ratyfikowane za uprzednią zgodą wyrażoną w ustawie umowy międzynarodowe, ustawy i rozporządzenia, a na obszarze działania organów, które je ustanowiły, także akty prawa miejscowego. Prawo wspólnotowe zaczęło obowiązywać w polskim porządku prawnym na mocy ratyfikowanego Traktatu o przystapieniu Rzeczypospolitej Polskiej do Unii Europejskiej ${ }^{24}$. W myśl art. 91 ust. 1 Konstytucji ratyfikowana umowa międzynarodowa, po jej ogłoszeniu w „Dzienniku Ustaw Rzeczypospolitej Polskiej”, stanowi część krajowego porządku prawnego i jest bezpośrednio stosowana, chyba że jej stosowanie jest uzależnione od wydania ustawy. Ustęp 2 tego artykułu stanowi, że umowa międzynarodowa ratyfikowana za uprzednia zgodą wyrażoną w ustawie ma pierwszeństwo przed ustawa, jeżeli ustawy tej nie da się pogodzić z umowa. W art. 91 ust. 3 Konstytucji stwierdza się, że jeżeli wynika to z ratyfikowanej przez Rzeczpospolitą Polską umowy konstytuującej organizację międzynarodowa, prawo przez nią stanowione jest stosowane bezpośrednio, mając pierwszeństwo w przypadku kolizji z ustawami.

\section{POLSKA DYSKUSJA O WZAJEMNYCH RELACJACH WYKŁADNI PROUNIJNEJ ORAZ WYKLADNI SYSTEMOWEJ}

Obowiązek dokonywania wykładni prounijnej, do którego stosowania polskie sądy zobligowane sa na podstawie wspomnianej ratyfikowanej umowy międzynarodowej, podkreślany jest zarówno na gruncie koncepcji derywacyjnej, jak i klaryfikacyjnej, a także w polskiej doktrynie prawa europejskiego. Na gruncie koncepcji klaryfikacyjnej pogląd taki reprezentuje Lech Morawski $^{25}$. Autor, wskazujacc na art. 91 ust. 3 Konstytucji Rzeczypospolitej Polskiej, stwierdza, że konsekwencją zasady prymatu prawa unijnego nad własnym prawem jest nakaz wyboru przy wykładni przepisów krajowych takiej ich interpretacji, która jest najbardziej przychylna dla prawa unijnego ${ }^{26}$. Natomiast Maciej Zieliński, przedstawiciel derywacyjnej koncepcji wykładni prawa, do dyrektyw wykładni systemowej zalicza również nakaz wykładni zgodnej z prawem unijnym. Należy przypomnieć, że autor skonstruował oryginalny, w założeniu uniwersalny, model wykładni prawa krajowego. Składa się on z trzech faz: porządkującej, rekonstrukcyjnej i percepcyjnej ${ }^{27}$. Podzielił dyrektywy wykładni według stopnia ich ważności, dzieląc je na zasady, reguły i wskazówki, na nowo je definiujacc, a następnie uszeregował w określony przez siebie schemat postępowania, który zrealizować winien interpretator, aby poprawnie dokonać interpretacji tekstu prawnego ${ }^{28}$. W tym ujęciu zasady to pragmatyczne dyrektywy wykładni, które wyznaczają podstawowe kierunki zachowań interpretacyjnych, reguły wskazuja, jaką czynność interpretacyjną należy zrealizować przy spełnieniu określonych warunków, a wskazówki określaja, jak osiagnać rezultat wyznaczony w regułach, lub ustalają sens

\footnotetext{
${ }^{24}$ Dz. U. 2004, Nr 90, poz. 864.

25 Por. L. Morawski, Zasady..., s. 143- 147.

26 Ibidem, s. 143-147.

${ }_{27}$ Zob. M. Zieliński, op. cit., s. 314-344.

28 Ibidem, s. 286-293.
} 
uzyskanego rezultatu ${ }^{29}$. Autor, konstruując swój derywacyjny model wykładni prawa krajowego, włączył do niego również dyrektywę wykładni prouninijnej, którą uznał za dyrektywę interpretacyjną systemową i nadał jej rangę reguły. Ma ona zastosowanie jedynie w ostatniej, percepcyjnej fazie wykładni. Reguła oznaczona w derywacyjnym algorytmie numerem 21 (a zatem druga reguła wykładni systemowej fazy percepcyjnej) nakazuje zgodnie z dyrektywami systemowymi pionowymi sprawdzić m.in., czy treść normy jest zgodna z normami prawa Unii Europejskiej, a reguła numer 22 nakazuje odrzucić takie znaczenie interpretowanego zwrotu, który prowadziłby do konfliktu pionowego norm. Należy zaznaczyć, że w derywacyjnym modelu wykładni dyrektywy systemowe wykładni maja zastosowanie jedynie w wariancie pierwszym fazy percepcyjnej, a zatem jedynie wówczas, gdy wynik osiagnięty za pomocą zastosowania dyrektyw językowych wykładni nie jest jednoznaczny ${ }^{30}$.

W polskiej doktrynie prawa europejskiego przeważa pogląd, że nakaz dokonywania wykładni przepisów prawa krajowego w zgodzie z prawem unijnym (wcześniej wspólnotowym) jest dyrektywą wykładni systemowej. Taką opinię wyraził Adam Łazowski ${ }^{31}$. Podobne stanowisko zaprezentował Jarosław Dudzik, stwierdzając, że „z punktu widzenia teorii prawa, sięgnięcie przez organ stosujący prawo po regulację wspólnotową w celu ustalenia treści normy prawnej wynikającej z przepisu krajowego należy uznać za przejaw wykładni systemowej" ${ }^{32}$. Dalej autor ten stwierdza, że „sięgnięcie przez organ stosujący prawo po regulację wspólnotową w celu ustalenia treści normy prawnej” może być „postrzegane jako element wykładni celowościowej lub funkcjonalnej” ${ }^{33}$. Również Joanna Helios uważa nakaz dokonywania wykładni przepisów prawa krajowego w zgodzie z prawem unijnym za dyrektywę wykładni systemowej, przy czym argumentem przemawiającym za tym stanowiskiem ma być zdaniem autorki to, że obowiązek jej dokonywania został sformułowany i rozbudowany w orzecznictwie Trybunału Sprawiedliwości ${ }^{34}$. Z kolei analizując dyskusję w piśmiennictwie na temat charakteru wykładni prounijnej, Krystyna Kowalik-Bańczyk nie dała jednoznacznej odpowiedzi, czy uważa ją za wykładnię systemową czy też funkcjonalną lecz stwierdziła, że „obie formy wykładni mogą być użyteczne. Częściej przywoływane jest uzasadnienie celowościowe, jednak sięgnięcie po argumenty systemowe dla uzasadnienia określonego rozumienia przepisów polskich może się okazać również przekonujące" ${ }^{35}$.

Należy zauważyć, że w piśmiennictwie można spotkać stanowisko odmienne, nieutożsamiające nakazu wykładni przepisów krajowych w zgodzie z prawem unijnym z dyrektywą wykładni systemowej. Krzysztof Płeszka, adaptując na grunt koncepcji klaryfikacyjnej najbardziej rozpowszechniony w nauce

29 Ibidem.

${ }^{30}$ Ibidem, s. 338 .

${ }^{31}$ Por. A. Łazowski, Proeuropejska wykładnia prawa przez polskie sqdy i organy administracji jako mechanizm dostosowania systemu prawnego do acquis communautaire, w: E. Piontek (red.), Prawo polskie a prawo Unii Europejskiej, Warszawa 2003, s. 191.

32 J. Dudzik, op. cit., s. 174.

33 Ibidem.

${ }^{34}$ Por. J. Helios, Pojmowanie wyktadni prawa europejskiego w orzecznictwie Trybunału Sprawiedliwości, Wrocław 2002, s. 138-139.

35 Por. K. Kowalik-Bańczyk, op. cit., s. 11. 
prawa europejskiego sposób dokonywania wykładni prounijnej, czyli model wzorca interpretacyjnego, doszedł do wniosku, że jest to w istocie model wykładni operatywnej dokonywanej przez organy stosujące prawo państw członkowskich w pewnej szczególnej sytuacji interpretacyjnej ${ }^{36}$. Warto w tym miejscu przypomnieć, że w polskiej doktrynie prawa europejskiego zaproponowany został sposób dokonywania wykładni prounijnej, nazwany modelem wzorca interpretacyjnego, polegający, mówiąc w dużym uproszczeniu, na odrębnym ustaleniu znaczenia przepisu prawa krajowego oraz unijnego (to ów wzorzec interpretacyjny), a następnie ich porównaniu i dostosowaniu normy krajowej w taki sposób, aby zgodna była z unijnym wzorcem ${ }^{37}$. Krzysztof Płeszka, opisując proponowany przez siebie model wykładni prounijnej, posługuje się sformułowaniami, z których wywnioskować można, że nie uważa wykładni prounijnej za taka, w ramach której jednorazowo stosuje się dyrektywę interpretacyjna, ale traktuje ją jako taka, w ramach której stosuje się dyrektywy interpretacyjne dotyczace całego procesu interpretacji (przykładowo świadczy o tym używanie zwrotu ,zachowanie prowspólnotowości interpretacji wymaga, by w każdym przypadku [...]" ${ }^{38}$ ).

Nie utożsamia nakazu wykładni prounijnej z dyrektywą wykładni systemowej także Maciej Koszowski, który traktuje ją jako swoiste zadanie interpretatora, mającego dążyć do zapewnienia zgodności prawa krajowego z prawem unijnym $^{39}$. Autor proponuje odmienny od modelu wzorca interpretacyjnego schemat postępowania interpretatora nazwany przez niego modelem harmonizacji kontekstów, polegający na odwoływaniu się do prawa unijnego na każdym poziomie procesu interpretacji, począwszy od językowego, przez systemowy, po funkcjonalny ${ }^{40}$. Autor uważa nawet, że wykładnia prounijna „może być wpleciona w strukture wnioskowania per analogiam" ${ }^{11}$. Oznacza to, zdaniem tego autora, że dokonując interpretacji tekstu prawa krajowego w świetle prawa Unii Europejskiej, interpretator nie jest ograniczony do wykładni sensu stricto, do której należą dyrektywy wykładni systemowej, ale może odwołać się do wnioskowań prawniczych należących już do wykładni sensu largo.

Zbliżony pogląd na nakaz dokonywania interpretacji prounijnej prezentuje także Krzysztof Oplustil, argumentując, że nie można go redukować do reguły pierwszeństwa przy wyborze jednego z wyników tradycyjnych metod wykładni, ale cele i brzmienie unijnej regulacji trzeba mieć na uwadze przy stosowaniu każdej z tych metod, a zatem w czasie całego procesu interpretacji ${ }^{42}$. Wydaje się, że wykładni prounijnej z wykładnią systemową nie utożsamiają także

${ }^{36}$ K. Płeszka, op. cit., s. 266.

${ }^{37}$ C. Mik, op. cit., s. 115-165. Termin „model wzorca interpretacyjnego” przyjałem za M. Koszowski, Wyktadnia prowspólnotowa..., s. 78. Sformułowanie „model” rozumiane jest jako jeden z proponowanych sposobów przeprowadzania procesu wykładni, a „wzorzec” oznacza nazwę funkcji dla wyinterpretowanej normy prawa unijnego - jest ona wzorcem dla normy krajowej.

${ }^{38}$ K. Płeszka, op. cit., s. 272.

${ }^{39}$ M. Koszowski, Wyktadnia prowspólnotowa..., s. 78; M. Koszowski, Dwa modele wykładni prounijnej, „Studia Iuridica Lublinensia” 2012, nr 18, s. 43-58.

${ }^{40}$ M. Koszowski, Dwa modele wyktadni prounijnej, „Studia Europejskie” 2012, z. 3, s. 93-110.

${ }^{41}$ M. Koszowski, Wyktadnia prowspólnotowa..., s. 91.

${ }^{42}$ K. Oplustil, O potrzebie proeuropejskiej wyktadni polskiego prawa spótek, „Przegląd Prawa Handlowego" 2009, z. 9, s. 5. 
Patrycja Zawirska i Magdalena Zwolińska, skoro twierdza, że w „w ujęciu doktrynalnym, proeuropejska wykładnia prawa krajowego stała się odrębna konstrukcją prawna, służącą zapewnieniu prawu wspólnotowemu należytej efektywności”" ${ }^{\prime 3}$. Autorki jednak nie analizuja szerzej tego zagadnienia.

Jeszcze inaczej opisuje wykładnię prounijną Konrad Łuczak. W pierwszym rzędzie określa jej istotę jako „prawne zobowiązanie sądu państwa członkowskiego do sformułowania decyzji interpretacyjnej przepisów prawa krajowego znajdujących zastosowanie w sprawie, o treści odpowiadającej brzemieniu i celom odpowiedniej dyrektywy, a na podstawie której to decyzji można wydać rozstrzygnięcie gwarantujące osiagnięcie rezultatu przepisanego dyrektywa ${ }^{44}$. W drugim rzędzie wskazuje, że na wykładnię zgodna z prawem unijnym składa się aspekt apragmatyczny i pragmatyczny. Pierwszy ujmuje wykładnię jako efekt przeprowadzonej wcześniej wykładni tekstu prawnego, a drugi jako procedurę (proces) dokonywania wykładni. W jego przekonaniu proces wykładni zgodnej ma dwa etapy: krajowy - oznaczający dokonywanie czynności interpretacyjnych wobec prawa krajowego oraz wspólnotowy (obecnie należało nazwać go unijnym) - polegający na rekonstrukcji wzorca przez wykonywanie czynności interpretacyjnych na przepisach prawa wspólnotowego ${ }^{45}$.

\section{WLASNA PROPOZYCJA ROZSTRZYGNIECCIA SPORU DOTYCZĄCEGO RELACJI POMIĘDZY WYKŁADNIĄ PROUNIJNĄ A SYSTEMOWĄ}

Powyższy przegląd piśmiennictwa, chociaż z pewnością niepełny, pokazuje, że pogląd, iż nakaz dokonywania wykładni przepisów prawa krajowego w zgodzie z prawem unijnym jest dyrektywa wykładni systemowej, nie jest bezdyskusyjny. Za jego przyjęciem przemawia wskazane na wstępie założenie uporządkowania pionowego norm i umiejscowienie umów międzynarodowych ratyfikowanych za uprzednią zgodą wyrażoną w ustawie wysoko, zaraz po Konstytucji, w hierarchii aktów prawnych. Można jednak konieczność stosowania wykładni prounijnej uzasadniać w inny sposób niż przez odwołanie się do założenia uporządkowania pionowego norm - a mianowicie, jako prawny obowiązek spoczywający na organach stosujacych prawo państw członkowskich ${ }^{46}$. Przeciwko stanowisku redukującemu nakaz wykładni prounijnej do jednej z dyrektyw wykładni systemowej można sformułować, w mojej ocenie, cały szereg argumentów. Przede wszystkim należy wskazać na sposób przeprowadzania wykładni prounijnej. Jak już wyżej wspomniano, Trybunał Sprawiedliwości narzucił jedynie cel, ale jego osiagnięcie pozostawił metodom wykładni poszczególnych państw członkowskich. W polskim piśmiennictwie dominuje

\footnotetext{
${ }^{43}$ P. Zawirska, M. Zwolińska, Proeuropejska wyktadnia pojęcia przejścia zakładu pracy - kryterium tożsamości, „Monitor Prawa Pracy” 2010, nr 8, s. 403-407.

${ }^{44} \mathrm{~K}$. Łuczak, Metody wyktadni prawa krajowego a wyktadnia zgodna $z$ prawem unijnym ( $w$ orzecznictwie sadów administracyjnych), „Państwo i Prawo” 2011, z. 1, s. 60.

${ }^{45}$ K. Łuczak, op. cit., s. 61-62.

${ }^{46}$ Tak K. Łuczak, op. cit., s. 60 i M. Koszowski, Wyktadnia prawa krajowego..., s. 69-70.
} 
koncepcja modelu wzorca interpretacyjnego, ale nie jest ona pozbawiona wad. Należy wskazać jeszcze na wymieniony wyżej model harmonizacji kontekstów Macieja Koszowskiego, czy bazujacca na koncepcji derywacyjnej ideę sformułowaną przez Andżelikę Godek, polegająca na tworzeniu hybryd normatywnych (chociaż nietraktowany przez autorkę jako rodzaj wykładni prounijnej, to będący nim, w moim przekonaniu, gdyż prowadzący do wykładni przepisów krajowych w zgodzie z prawem unijnym) ${ }^{47}$. W obu ujęciach czynności interpretatora nie ograniczają się do fazy wykładni systemowej. Jak już wyżej wspomniano, w modelu harmonizacji kontekstów wykładnia prounijna polega na odwoływaniu się do normy unijnej na każdym etapie wykładni przepisu prawa krajowego, zarówno językowym, jak i systemowym czy funkcjonalnym, a nawet dozwolone jest odwoływanie się do wnioskowań prawniczych, które nie są przecież dyrektywami wykładni (wykładni sensu stricto, do których należą dyrektywy wykładni systemowej). W ujęciu A. Godek interpretator sięga natomiast do dyrektyw interpretacyjnych fazy rekonstrukcyjnej wykładni, podczas gdy dyrektywy systemowe należą do odmiennej kategorii, gdyż do reguł percepcyjnych wykładni. Autorka wyszła z założenia, że prawo unijne stanowi w istocie część prawa krajowego i nie można wykluczyć rozczłonkowania syntaktycznego poszczególnych elementów składających się na normę prawną w przepisach pochodzaccych od prawodawcy krajowego i prawodawcy unijnego. Opierając się na koncepcji derywacyjnej, wprowadziła pojęcie hybrydy normatywnej, czyli takiej normy postępowania, której poszczególne człony pochodzącą od różnych prawodawców, tj. unijnego i krajowego ${ }^{48}$. Należy przypomnieć, że w ujęciu derywacyjnym istotnym etapem procesu interpretacyjnego jest faza rekonstrukcyjna wykładni, polegająca na pozyskaniu wyrażania normokształtnego, będącego przedmiotem dalszych zabiegów interpretacyjnych w ostatniej, percepcyjnej fazie wykładni ${ }^{49}$. Andżelika Godek wskazuje na taki sposób interpretacji, w którym interpretator, chcąc pozyskać wyrażenie normokształtne już w fazie rekonstrukcyjnej wykładni, odwołuje się do przepisów prawa krajowego i prawa unijnego. W myśl koncepcji derywacyjnej wyrażenie normokształtne to taka wypowiedź, która zawiera wszystkie elementy syntaktyczne normy prawnej: nakaz określonego zachowania, okoliczności i adresata. W fazie rekonstrukcyjnej wykładni najpierw interpretator pozyskuje przepis zrębowy niezupełny, a zatem taki, który zawiera co najmniej operatora zakazu albo nakazu oraz zachowanie się będace przedmiotem jakiegoś obowiązku, a następnie uzupełnia go przepisem bądź przepisami uzupełniającymi. Hybryda normatywna to takie wyrażenie normokształtne, którego jeden fragment pochodzi od krajowego, a drugi - od unijnego prawodawcy.

Poza A. Godek możliwość powstania norm składających się z członów pochodzacych od prawodawcy krajowego i unijnego dopuszczają również

${ }^{47}$ Por. szerzej na temat modeli wykładni prounijnej - W. Rowiński, Dyskusja nad modelem wykładni prounijnej $w$ polskiej nauce prawa, „Adam Mickiewicz University Law Review” 2012, z. 1, s. 9-22.

${ }^{48}$ Zob. A. Godek, Zastosowanie derywacyjnej koncepcji wykładni prawa do rozstrzygania spraw ze stosowaniem przepisów unijnych, „Ruch Prawniczy, Ekonomiczny i Socjologiczny” 73, 2011, z. 1, s. 21-39.

${ }_{49}$ M. Zieliński, op. cit., s. 314-344. 
inni autorzy. Możliwość taką wprost i bez większych zastrzeżeń przewiduje Marta Kisielowska ${ }^{50}$. Natomiast Marcin Kamiński przewiduje ją w określonej, wyjątkowej sytuacji, a mianowicie wówczas, gdy na skutek niemożności dokonania wykładni prounijnej przepisów krajowych należy zastosować bezpośrednio normę unijna. $\mathrm{W}$ takiej sytuacji konieczne będzie - zdaniem autora - „skonstruowanie na podstawie bezpośrednio skutecznych przepisów dyrektywy i tzw. krajowego otoczenia normatywnego tych przepisów (np. zawartego w ustawach o podatku VAT lub o podatku akcyzowym) nowych norm, które łączą w sobie treść bezpośrednio skutecznych norm dyrektywy (zasadniczo zakazujących osiagnnięcia określonych rezultatów albo je nakazujących) oraz przepisów prawa krajowego ${ }^{51}$. W moim przekonaniu działanie polegające na tworzeniu nowych norm jest w istocie właśnie interpretacja. Termin „bezpośrednie stosowanie normy unijnej” powinien być zarezerwowany dla sytuacji, w której podmiot stosujacy prawo nie dokonuje już kolejnych zabiegów interpretacyjnych, a norma unijna wprost reguluje daną kwestię wynikająca $\mathrm{z}$ określonego stanu faktycznego. Konstruowanie normy prawnej złożonej z członów pochodzacych od unijnego i krajowego prawodawcy - w ramach wykładni prounijnej - spotkać można także $\mathrm{w}$ orzecznictwie ${ }^{52}$.

Należy zauważyć, że nawet w przypadku najbardziej rozpowszechnionej idei modelu wzorca interpretacyjnego trudno zaklasyfikować działania interpretatora jako stosowanie dyrektywy wykładni systemowej. W tym miejscu trzeba przypomnieć, że idea ta została zaproponowana nie przez teoretyków prawa, ale w doktrynie prawa europejskiego, bez odniesienia do określonej koncepcji wykładni prawa w Polsce. Polega - w pewnym uproszczeniu - na odrębnym ustaleniu znaczenia przepisu prawa krajowego oraz unijnego, a następnie ich porównaniu i dostosowaniu normy krajowej w taki sposób, aby zgodna była $\mathrm{z}$ unijnym wzorcem $^{53}$. Nawet w najprostszej sytuacji interpretacyjnej - kiedy istnieje możliwość wyboru kilku równorzędnych rozwiązań interpretacyjnych, a interpretator, chcąc zapewnić zgodność z prawem unijnym decyduje się na jedno z nich - należałoby raczej mówić o dyrektywie preferencji (metadyrektywie) niż o dyrektywie systemowej. Cały proces wykładni przepisu krajowego jest już bowiem zakończony, a interpretator podejmuje decyzję po zakończeniu wszystkich etapów wykładni przepisu krajowego, w tym stosowania reguł wykładni systemowej. W przypadku bardziej skomplikowanych sytuacji interpretacyjnych, przykładowo kiedy należy próbować dokonać wykładni rozszerzającej przepisu krajowego w celu zapewnienia zgodności z prawem unijnym,

${ }^{50}$ M. Kisielowska, Multicentryczność systemu norm prawa administracyjnego, „Samorząd Terytorialny" 2013, nr 5, s. 75-83.

${ }_{51}$ M. Kamiński, Konstruowanie wzorca legalności decyzji administracyjnej na podstawie prawa UE przez polskie sady administracyjne cz. II, „Europejski Przegląd Sądowy” 2011, z. 5, s. 27.

${ }^{52}$ Por. wyrok z 29 marca 2012 r., I PK 150/11, Lex, nr 1167736, w którym w ramach wykładni prounijnej Sąd Najwyższy konstruuje normę prawna, której jeden człon - definicję przejścia zakładu pracy - wynika z prawa unijnego, a drugi człon - skutki tego przejścia - z przepisu krajowego. Przepis krajowy - art. $23^{1}$ k.p. - stanowi przepis zrębowy niezupełny, który został uzupełniony za pomoca prawa unijnego.

${ }^{53}$ C. Mik, op. cit., s. 115-165. 
zabiegi interpretatora wymagają szeregu zabiegów interpretacyjnych, które nie mieszczą się w ramach stosowania dyrektywy systemowej ${ }^{54}$.

Warto podkreślić, że wymienione wyżej ujęcia wykładni obejmują na ogół cały szereg czynności interpretacyjnych. Czym innym jest - co powinno być oczywiste - dyrektywa wykładni, a czym innym zespół (grupa) dyrektyw. Nie wolno tych dwóch rzeczy utożsamiać, jeden desygnat nie jest bowiem grupa desygnatów. Skoro wykładnię prounijną realizuje się według określonego schematu postępowania, który co do zasady jest złożony, to nie sposób utrzymywać, że jest to stosowanie pojedynczej dyrektywy wykładni. Sama różnorodność zabiegów interpretacyjnych proponowanych w ramach poszczególnych ujęć dokonywania wykładni prounijnej świadczy o tym, że nie mamy do czynienia ze stosowaniem dyrektywy wykładni.

Przeczy też temu dopuszczalność - przynajmniej w niektórych ujęciach wykładni prounijnej - odwoływania się w toku dokonywania wykładni prounijnej do reguł wykładni innych niż systemowa (tak przykładowo przy hybrydach normatywnych czy modelu harmonizacji kontekstów), a nawet do wnioskowań prawniczych (model harmonizacji kontekstów). Przeprowadzony powyżej wywód pokazuje także różnorodność proponowanych w piśmiennictwie sposobów dokonywania wykładni prounijnej. Nie ma przy tym przemawiajacych za tym wystarczających argumentów ani teoretycznoprawnych, ani wskazówek wynikajacych ze stanowiska Trybunału Sprawiedliwości, aby opowiedzieć się - przynajmniej na obecnym etapie rozwoju nauki prawa - za jednym z ujęć. Kwestia ta będzie musiała być przedmiotem dalszych badań.

Słabość stanowiska, które utożsamia nakaz dokonywania wykładni prounijnej z dyrektywą wykładni systemowej, uwidacznia się w przypadku interpretacji prounijnej przepisów Konstytucji, którą co do zasady uważa się za dopuszczalna ${ }^{55}$. Skoro bowiem obowiązek wykładni prounijnej jest dyrektywa wykładni systemowej opartej na hierarchii aktów prawnych, określonej w samej Konstytucji, to - stojąc konsekwentnie na tym stanowisku - należałoby odmówić prounijnej wykładni przepisów konstytucyjnych. Nie może bowiem być tak, aby akt prawny najwyższej rangi w systemie prawnym zezwalajacy na stosowanie norm zawartych w akcie prawnym niższego rzędu, pozwalał zasadom wywodzącym się z aktu niższego rzędu na jakikolwiek wpływ na normy znajdujące się w akcie najwyższej rangi. Traci bowiem swoją nadrzędność akt prawny, gdy interpretowany jest w zgodzie z aktem niższego rzędu - np. interpretacja ustawy $\mathrm{w}$ zgodzie $\mathrm{z}$ rozporządzeniem. Tymczasem prounijna wykładnia przepisów konstytucyjnych, chociaż w ograniczonym zakresie, jest

${ }^{54}$ Por. szczegółowe rozważania na temat wykładni prounijnej, która doprowadzić ma do wykładni rozszerzającej, bazujące na koncepcji klaryfikacyjnej - K. Płeszka, op. cit., s. 266-274.

${ }_{55}$ Por. szerzej na temat wykładni prounijnej przepisów konstytucyjnych - K. Działocha, Podstawy prounijnej wykładni RP, „Państwo i Prawo” 2004, z. 11, s. 28-33; A. Kustra, Kolizje norm konstytucyjnych $i$ wspólnotowych w ujęciu teoretycznoprawnym, „Europejski Przegląd Sądowy” 2007, nr 5, s. 23-31; A. Madeja, Wyktadnia prounijna w orzecznictwie Polskiego Trybunału Konstytucyjnego (1997-2005), „Studia Iuridica Toruniensia” 8, 2011, s. 142-167; J. Maśnicki, Kontrola konstytucyjności instrumentów implementujacych prawo pochodne Unii Europejskiej, „Państwo i Prawo" 2015, z. 6, s. 67-81. 
jednak dopuszczalna zarówno w doktrynie, jak i orzecznictwie ${ }^{56}$. Przeczy to moim zdaniem - możliwości określania nakazu interpretacji prawa krajowego w zgodzie z prawem unijnym jako jednej z dyrektyw systemowych wykładni, opartej na założeniu hierarchiczności aktów normatywnych.

Ze względu na tematykę i ramy niniejszego artykułu nie jest możliwa szczegółowa analiza charakteru nakazu dokonywania wykładni przepisów prawa krajowego w zgodzie z prawem unijnym. Uważam jednak, że należy w tym miejscu zasygnalizować, że punktem wyjścia próby odpowiedzi na pytanie o charakter tego nakazu powinno być odwołanie się do rozróżnienia poczynionego przez stwierdzenia Andrzeja Batora i Artura Kozaka na kanwie rozważań o wykładni zgodnej z konstytucja, którą w ich przekonaniu można rozważać zarówno z perspektywy metod, jak i ideologii wykładni. Autorzy ci uznali, że z punktu widzenia metod interpretacji wykładnia w zgodzie z konstytucja nie jest nowa techniką (metoda) wykładni, ale zbiorem dotychczas stosowanych reguł interpretacji, natomiast z punktu widzenia ideologii jest pewnym postulatem (powinnościa, norma) wyrastajacym z określonej kultury prawnej ${ }^{57}$. Nie czyniąc analogii pomiędzy wykładnią zgodną z konstytucja i wykładnia prounijna, a jedynie korzystając z poczynionego przez tych autorów rozróżnienia, uważam, że nakaz dokonywania wykładni przepisów prawa krajowego w zgodzie z prawem unijnym należy traktować jako powinność, która spoczywa na interpretatorze przez cały proces interpretacji, począwszy od sprawdzenia, czy zachodza przesłanki do uruchomienia procedury związanej z wykładnia prounijną (a zatem czy sprawa ma unijny charakter), aż po zakończenie całego procesu interpretacji (ustalenie, że norma prawa krajowego jest zgodna z prawem unijnym, doprowadzenie do zgodności normy prawa krajowego z prawem unijnym albo uznanie, że w danej sprawie nie jest to możliwe). Rolą poszczególnych koncepcji wykładni prawa w państwach członkowskich jest zaproponowanie takiego modelu wykładni, aby można było się z tego obowiązku wywiązać. Z punktu widzenia metod interpretacji wykładnia prounijna (w znaczeniu pragmatycznym) jest zespołem czynności interpretacyjnych, przewidzianych w określonym modelu wykładni, stworzonym w ramach danej koncepcji wykładni, aby owa powinność w pełni zrealizować.

\section{PODSUMOWANIE}

Analiza problematyki relacji pomiędzy wykładnią prounijną a systemowa pozwala stwierdzić, że nie ma wystarczających argumentów umożliwiających przyjęcie, że nakaz dokonywania wykładni prounijnej to jedna z dyrektyw wykładni systemowej. Za takim stanowiskiem przemawia jedynie sposób, w jaki uzasadnia się obowiązek stosowania wykładni prounijnej, a mianowicie przez

${ }^{56}$ K. Działocha, op. cit., s. 28-33; wyrok TK z 27 maja 2003 r., K 11/03, OTK ZU A/5 (58), poz. 43, s. 576 i wyrok TK z 21 kwietnia 2004 r., K 33/03, OTK ZU A/4 (66), poz. 31, s. 432-433.

${ }_{57}$ Por. A. Bator, A. Kozak, Wyktadnia prawa $w$ zgodzie $z$ Konstytucja, w: S. Wronkowska (red.), Polska kultura prawna a proces integracji europejskiej, Kraków 2005, s. 54-55. 
odwoływanie się do hierarchii aktów prawnych, gdzie prawo unijne zajmuje wysokie, gdyż drugie po Konstytucji, miejsce. Wydaje się jednak, że obowiązek stosowania wykładni prounijnej uzasadniać można na innej płaszczyźnie niż odwołanie się do założenia uporządkowania pionowego norm w systemie prawnym - a mianowicie jako prawny obowiązek spoczywajacy na organach stosujacych prawo państwa członkowskiego, nakazujący wszczęcie pewnej procedury interpretacyjnej w przypadku wystapienia określonych przesłanek. Poglądowi klasyfikującemu nakaz wykładni prounijnej jako dyrektywę wykładni systemowej przeciwstawić można cały szereg argumentów, począwszy od metod jej dokonywania, poprzez sposób opisywania, a skończywszy na dopuszczalności prounijnej wykładni przepisów krajowych o randze konstytucyjnej. Szczególnie znamienna jest rozmaitość proponowanych modeli dokonywania wykładni prounijnej, a także różnorodność i złożoność czynności interpretacyjnych podejmowanych w ich ramach. Uważam, że nakaz wykładni prounijnej należy traktować jako powinność dotyczącą całego procesu interpretacji, a nie jako dyrektywę wykładni systemowej.

mgr Wojciech Rowiński

Uniwersytet im. Adama Mickiewicza w Poznaniu

wojciechrowinski@yahoo.com

\section{OBLIGATION TO APPLY A PRO-EUROPEAN INTERPRETATION AS A DIRECTIVE OF A SYSTEMIC INTERPRETATION}

Sum mary

The aim of the article is to attempt to analyse the debate in Polish jurisprudence about the relationship between the pro-EU interpretation and the systemic interpretation. The prevailing opinion about the status of the pro-EU interpretation in Polish jurisprudence is that it is one of the rules of the systemic interpretation. Reaching the basic notions of the theory of law and analysing the models for implementing the pro-EU interpretation proposed by the doctrine of European law and that put forward by Polish theory, of law the author comes to the conclusion that is not possible to classify the pro-EU interpretation as a directive of interpretation of the systemic interpretation. 
